\title{
Impact of Organic and Inorganic Fertilizers on Nematode Reproduction and Biochemical Alterations on Tomato
}

\author{
Ahmed A. FARAHAT', Alsayed A. ALSAYED ${ }^{1}$, Hossam S. EL-BELTAGI ${ }^{2 *}$, Nomair M. MAHFOUD' \\ ${ }^{1}$ Cairo University, Faculty of Agriculture, Zoology and Agricultural Nematology Deptartment, Cairo, Egypt \\ ${ }^{2}$ Cairo University, Faculty of Agriculture, Biochemistry Deptartment, P. Box 12613, Gamma \\ Street, Giza, Cairo, Egypt; lbltg@yahoo.com ('corresponding author)
}

\begin{abstract}
The organic amendments, compost, neem and poultry as well as inorganic fertilizer, N P K and nematicide Nemacur 10\% G applied singly at two different doses were effective in reducing $M$. incognita number of galls, nematode reproduction and fecundity. Also, they ameliorated growth criteria of treated tomato plants. The effectiveness seemed to be material origin and concentration dependent. Neem, compost 1,3 at higher doses $(5 \mathrm{~g} /$ pot $)$ gave the best results. Yet, achieved results were less than those of nemacur $10 \% \mathrm{G}$ which overmatched all the organic and inorganic fertilizers. Nematode infection reduced total soluble sugars in roots but the opposite was the case in all treatments. Nematode infection supported root contents of amino acids, total phenols and tannins but they were diminished as a result of almost all treatments. Total soluble sugars and total carbohydrates in shoots decreased as a result of nematode infection but they were regained only by application of inorganic fertilizer. Total amino acids increased in shoots of infected plants and more increase was observed in almost all treatments. Nematode infection impaired tomato uptake of N P K; organic and inorganic fertilizers provoked plants up take, however nemacur improved plants up take of nitrogen only.
\end{abstract}

Keywords: Meloidogyne incognita, organic fertilizers, inorganic fertilizers, biochemical alterations

\section{Introduction}

Application of organic matter to the soil is known to have beneficial effects on soil nutrition, soil physical conditions, soil biological activities and crop performance (Efthimiadou et al., 2010). In addition, these materials have also been investigated as an alternative method of nematode management (Akhtar and Mahmood, 1996). Plants grown in soil that is high in organic matter often are less damaged by nematodes than plants grown in soil with less organic matter content (Al-Rehiayani, 2001; Efthimiadou et al., 2009). Any kind of organic soil amendment including compost can both improve tolerance of plant to nematodes and also reduce nematode populations. However, they cannot eliminate a severe nematode infestation. They are better suited to keep nematode population relatively low than reducing high ones (Crow and Dunn, 1994). Reductions in population densities of phytoparasitic nematodes in response to application of animal-culture manure especially poultry droppings and their positive effects on host growth have been reported in many studies (Ahmad and Siddiqui, 2009; Farahat et al., 1999). Neem, Azadirachta indica as a potanical material has been reported to posses nematotoxic activity due the content of limonoids and azadrachtin (Strilling, 1991). Addition of neem to the soil depressed phytonematodes populations (Anjum et al., 1996). There has been considerable progress in the use of compost as soil amendment for the control of plant parasitic nematodes in infested fields (Akhtar and Malik, 2000; McSorley et al., 1999; Zhang and Zhang, 2009).

The research approach of using inorganic fertilizers to diminish nematodes and maximize the benefits of fertilizer started in 1955, when Oteifa reported that ammonia decreased the counts of $M$. incognita females and eggmasses produced on infected lima beans. Many reports have been published dealing with that field of study (Akhtar et al., 1998; Kheir et al., 2009; Oteifa, 1955; Sinha and Neog, 2003).

Chemical alterations in plant tissues due to root-knot nematode infection had been extensively studied. Such alterations included total and reduced sugars, total carbohydrates, total, soluble and insoluble protein and amino acids, phenols, fatty acids as well as minerals in different host plants (Alam et al., 1976; Farahat et al., 2007; Jain and Kant, 1991; Nasr et al., 1980; Parveen et al., 2006; Sharma and Trivedi, 1997; Shuying and Zhixin, 1999).

The aim of current study was to investigate the impact of organic and inorganic fertilizers on nematode reproduction and its effects on the biochemical constitutes on tomato.

\section{Materials and methods}

One month old tomato (Lycopersicon esculentum) seedlings cv. 'GS' with uniform size were transplanted singly 
in $15 \mathrm{~cm}$ clay pots filled with virgin sandy soil. One week after transplantation, the following materials were applied at two doses as illustrated in Tab. 1. Materials were incorporated with the pot soil around the plant. Each treatment was replicated four times. One week later, each pot was inoculated with 3000 freshly hatched juveniles $\left(J_{2}\right)$ of Meloidogyne incognita by pouring the nematode water suspension into 4 holes around root system and immediately covered with sand. Control pots were inoculated and kept free from any material as well as non inoculated healthy plants. All treatments were arranged on a greenhouse clean bench at $32 \pm 5^{\circ} \mathrm{C}$ and watered daily for 45 days. Then, plants were lifted out and data on plant growth were recorded and nematode population in soil and roots was counted. Shoots and roots of healthy and infected plants from the treatments of the higher doses $(5 \mathrm{~g} /$ pot of organic matter, 0.2 of the nematicide) were harvested for chemical analysis.

Total soluble sugars, total carbohydrates and total amino acids were determined by colorimetric methods (Chow and Landhausser, 2004; Etsushiro et al., 1981). Total phenol content was determined by the Folin-Ciocalteu method described by Meda et al. (2005) and tannins using vanillin hydrochloric acid method according to Burns (1971). Nitrogen was determined according to the method described by A.O.A.C. (1995), phosphorus according to El-Merzabani et al. (1997) and Potassium using Advanced Microwave Digestion system, ETHOS1 (ICP Spectrometer (iCAP 6000 Series; Thermo Scientific).

Tab. 1. The organic and inorganic fertilizers treatments

\begin{tabular}{ccc}
\hline Treatments & Material & Dose $(\mathrm{g} /$ pot $)$ \\
\hline 1 & Nemacur10\%G & 0.1 \\
2 & Nemacur10\%G & 0.2 \\
3 & Compost 1 & 2.5 \\
4 & Compost 1 & 5.0 \\
5 & Compost 2 & 2.5 \\
6 & Compost 2 & 5.0 \\
7 & Compost 3 & 2.5 \\
\hline 8 & Compost 3 & 5.0 \\
9 & Neem & 2.5 \\
10 & Neem & 5.0 \\
11 & Poultry & 2.5 \\
12 & Poultry & 5.0 \\
13 & A three & 1.0 \\
14 & A three & 2.0 \\
15 & N P K & $0.3: 0.1: 0.3$ \\
16 & N P K" & $0.6: 0.2: 0.6$ \\
17 & untreated inoculated & \\
18 & untreated healthy \\
\hline
\end{tabular}

${ }^{*} 1 / 2$ dose, ${ }^{* *}$ recommended dose Compost 1 (Rice straw + Okara + Rock phosphate, C/N ratio 33.94), Compost 2 (Rice straw + Okara + Rock phosphate + Composite inoculum $\mathrm{C} / \mathrm{N}$ ratio 32.13), compost 3 (Rice straw + Okara+ Rock phosphate + Composite inoculum + buffalo manure $\mathrm{C} / \mathrm{N}$ ratio 32.73). The three types of compost were produced (Rashad et al., 2010) and obtained from Microbiology Department, Faculty of Agriculture, Cairo University
Reducing sugars and total fatty acids were determined according to Holme and Peck (1983) and Farag et al. (1986) respectively.

Statistical analysis was carried out using Analysis of Variance (ANOVA) of MSTAT-C statistical package (Michigan State University) (MSTAT-C 1989).

\section{Result and discussion}

\section{Nematode development and reproduction}

Data presented in Tab. 2 reveal that all tested organic amendments applied at the two doses $(2.5,5.0 \mathrm{~g} / \mathrm{pot})$ significantly impaired gall formation, juveniles recovered from the soil, the numbers of the developmental stages, eggmasses, size of nematode population, nematode build up and egg production as compared with the untreated check with few exceptions. With regard to the treatments concentration, differences in nematode suppression were distinguishable. Although the lower dose of compost 3 and the higher one of compost 2 increased significantly the number of eggmasses/g root, they significantly decreased nematode fecundity (eggs/eggmass). In contrast, the lower dose of compost 1 and the higher one of poultry significantly increased egg production. Differences in nematode reductions were obvious among treatments and/or doses, the higher the dose the higher the reduction in nematode numbers except for poultry droppings. Neem, compost 1 and compost 3 at higher doses, in that order, gave the best results.

Concerning the inorganic fertilizer, N P K, treatments behaved differently. It is interesting to notice that the commercial product (A three ${ }^{\circ}$ ) was more effective in suppressing the nematode developmental stages, eggmasses and gall formation than the prepared N P K. The lower dose of the compound N P K (0.3:0.1:0.3 g/pot) significantly increased nematode criteria and poorly enhanced nematode reproduction.

The utmost reductions in over all values of nematode criteria were achieved by Nemacur $10 \%$ G at the two doses. The nematicide protects the roots from nematode invasion which resulted in sharp reduction in the number of galls, eggmasses, and fecundity and smashing the nematode build up.

The present results emphasized that all organic and inorganic fertilizers exhibited potential activity against the root-knot nematode and improved growth criteria of tomato irrespective of their origin or concentration. All the tested materials including N P K significantly suppressed root-galling, the number of eggmasses, egg production and subsequently the final population. However, the botanical material, neem, seemed to have higher toxic action much more than animal culture, compost and inorganic fertilizer but not as much as nemacur $10 \% \mathrm{G}$ which overwhelmed all other treatments. Many reports in literature emphasized the role of neem in controlling plant-parasitic nematodes (Farahat et al., 2008; Zaki and Bahati, 1989). 
50

Tab. 2. Reproduction of $M$. incognita as influenced by organic and inorganic fertilizers

\begin{tabular}{|c|c|c|c|c|c|c|c|c|c|c|}
\hline Treatments & $\begin{array}{c}\text { Dose/pot } \\
(\mathrm{g})\end{array}$ & Galls/root & $\begin{array}{c}\text { Galls/g } \\
\text { root }\end{array}$ & $\begin{array}{l}\text { Embedded } \\
\text { stages/root }\end{array}$ & $\begin{array}{c}\text { Egg } \\
\text { masses/root }\end{array}$ & $\begin{array}{c}\text { Soil } \\
\text { population }\end{array}$ & $\begin{array}{c}\text { Final } \\
\text { Population }\end{array}$ & $\begin{array}{c}\% \\
\text { Reduction } \\
\end{array}$ & $\begin{array}{c}\text { Eggs/ egg } \\
\text { mass }\end{array}$ & $\mathrm{Pf} / \mathrm{Pi}$ \\
\hline Nemacur & 0.1 & $12^{p}$ & $1^{\mathrm{j}}$ & $5^{\circ}$ & $12^{\circ}$ & $0^{\mathrm{P}}$ & 17 & 99.9 & $130^{\mathrm{h}}$ & 0.01 \\
\hline Nemacur & 0.2 & $6^{\mathrm{P}}$ & $1^{j}$ & $0^{\circ}$ & $6^{\circ}$ & $0^{\mathrm{p}}$ & 6 & 100.0 & $130^{\mathrm{h}}$ & 0.00 \\
\hline Compost 1 & 2.5 & $1581^{\mathrm{b}}$ & $99^{c}$ & $1125^{c}$ & $924^{g}$ & $4248^{\mathrm{h}}$ & 6297 & 58.0 & $210^{\mathrm{d}}$ & 2.10 \\
\hline Compost 1 & 5.0 & $770^{\mathrm{k}}$ & $58^{f g}$ & $427^{1}$ & $479^{1}$ & $1563^{\mathrm{n}}$ & 2469 & 83.5 & $210^{\mathrm{d}}$ & 0.82 \\
\hline Compost 2 & 2.5 & $1093^{g}$ & $67^{7^{\mathrm{ff}}}$ & $798^{i}$ & $701^{i}$ & $5416^{f}$ & 6915 & 53.8 & $154^{g}$ & 2.30 \\
\hline Compost 2 & 5.0 & $1495^{c}$ & $86^{\mathrm{d}}$ & $715^{j}$ & $1352^{\mathrm{b}}$ & $3910^{j}$ & 5977 & 60.1 & $193^{\mathrm{c}}$ & 1.99 \\
\hline Compost 3 & 2.5 & $1452^{\mathrm{d}}$ & $81^{\mathrm{d}}$ & $1518^{b}$ & $1210^{c}$ & $1960^{1}$ & 4688 & 68.7 & 96 & 1.56 \\
\hline Compost 3 & 5.0 & $349^{\circ}$ & $19^{\mathrm{i}}$ & $174^{\mathrm{n}}$ & $601^{\mathrm{k}}$ & $2115^{k}$ & 2890 & 80.7 & $113^{\mathrm{i}}$ & 0.96 \\
\hline Neem & 2.5 & $1007^{\mathrm{h}}$ & $59^{\mathrm{fg}}$ & $1105^{\mathrm{d}}$ & $614^{k}$ & $1880^{\mathrm{m}}$ & 3599 & 76.0 & $170^{\mathrm{f}}$ & 1.20 \\
\hline Neem & 5.0 & $480^{\mathrm{m}}$ & $32^{\mathrm{h}}$ & $818^{\mathrm{h}}$ & $250^{\mathrm{n}}$ & $980^{\circ}$ & 2048 & 86.3 & $163^{\mathrm{fg}}$ & 0.68 \\
\hline Poultry & 2.5 & $1253^{\mathrm{c}}$ & $70^{c}$ & $635^{\mathrm{k}}$ & $1079^{c}$ & $5060^{g}$ & 6774 & 54.8 & $192^{\mathrm{c}}$ & 2.26 \\
\hline Poultry & 5.0 & $976^{\mathrm{i}}$ & $56^{\mathrm{g}}$ & $1088^{\mathrm{c}}$ & $768^{\mathrm{h}}$ & $12250^{\mathrm{b}}$ & 14106 & 5.8 & $300^{a}$ & 4.70 \\
\hline A three" & 1.0 & $953^{j}$ & $63^{\mathrm{cfg}}$ & $1073^{f}$ & $1004^{f}$ & $6900^{c}$ & 8977 & 40.1 & $197^{\mathrm{c}}$ & 2.99 \\
\hline A three & 2.0 & $375^{\mathrm{n}}$ & $27^{\text {hi }}$ & $288^{\mathrm{m}}$ & $344^{\mathrm{m}}$ & $4230^{i}$ & 4862 & 67.5 & $310^{a}$ & 1.62 \\
\hline N PK & $1 / 2$ dose & $1844^{a}$ & $111^{\mathrm{b}}$ & $1972^{a}$ & $1850^{a}$ & $11500^{c}$ & 15322 & -2.3 & $162^{\mathrm{fg}}$ & 5.11 \\
\hline NPK & rec. dose & $573^{1}$ & $31^{\mathrm{h}}$ & $722^{j}$ & $639^{j}$ & $7130^{d}$ & 8491 & 43.3 & $276^{\mathrm{b}}$ & 2.83 \\
\hline Control & & $1198^{f}$ & $272^{a}$ & $1045^{\mathrm{g}}$ & $1123^{\mathrm{d}}$ & $12810^{a}$ & 14978 & - & $218^{\mathrm{d}}$ & 4.99 \\
\hline
\end{tabular}

In each column, means followed by the same letter $(s)$ are not significantly different $(P \leq 0.05)$ according to Duncan's multiple range test

The nematicidal activity of neem is due mainly to its content of limonoids and azadrachtin (Strilling, 1991).

\section{Plant growth response}

Improvement in plant growth parameters in terms of shoot and root lengths and weights was variable and proportional with the organic and inorganic single treatments concentration Tab. 3. The plants reacted differently according to specific material and an outstanding ame- lioration was more pronounced in shoot and root fresh weights. There were significant differences between (but not within) many treatments and the control. Increasing nemacur $10 \% \mathrm{G}$ dose increased significantly root criteria but not shoot ones. Some phytotoxicity were observed on plants received the higher nematicide dose. Doubling the concentration of organic and inorganic fertilizers significantly increased shoot length, dry weight, root length within treatments in many cases. N P K double dose in-

Tab. 3. Growth response of tomato seedlings infected with $M$. incognita as influenced by organic and inorganic fertilizers

\begin{tabular}{|c|c|c|c|c|c|c|c|c|c|}
\hline \multirow{3}{*}{ Treatments } & \multirow{3}{*}{$\begin{array}{c}\text { Dose/pot } \\
(\mathrm{g})\end{array}$} & \multicolumn{8}{|c|}{ Growth criteria } \\
\hline & & \multicolumn{5}{|c|}{ Shoot } & \multicolumn{3}{|c|}{ Root } \\
\hline & & $\begin{array}{l}\text { Length } \\
(\mathrm{cm})\end{array}$ & $\begin{array}{c}\text { Fresh Weight } \\
(\mathrm{g})\end{array}$ & $\begin{array}{c}\% \\
\text { increase }\end{array}$ & $\begin{array}{l}\text { Dry Weight } \\
(\mathrm{g})\end{array}$ & $\begin{array}{c}\% \\
\text { increase }\end{array}$ & $\begin{array}{l}\text { Length } \\
(\mathrm{cm})\end{array}$ & $\begin{array}{c}\text { Fresh Weight } \\
(\mathrm{g})\end{array}$ & $\begin{array}{c}\% \\
\text { increase }\end{array}$ \\
\hline Nemacur & 0.1 & $30.3^{-a-d}$ & $14.3^{\text {dh }}$ & 225 & $2.7^{\mathrm{fg}}$ & 80 & $26.5^{\mathrm{cf}}$ & $4.0^{\mathrm{fg}}$ & 48 \\
\hline Nemacur & 0.2 & $24.0^{\mathrm{fh}}$ & $12.5^{\mathrm{jk}}$ & 184 & $2.9^{\mathrm{d}-\mathrm{f}}$ & 93 & $32.0^{\mathrm{b}-\mathrm{c}}$ & $4.4^{\mathrm{cog}}$ & 63 \\
\hline Compost 1 & 2.5 & $27.0^{c-f}$ & $13.2^{i-k}$ & 200 & $2.8^{\mathrm{ef}}$ & 87 & $30.0^{b-c}$ & $6.0^{\mathrm{d}-\mathrm{f}}$ & 122 \\
\hline Compost 1 & 5.0 & $26.3^{\mathrm{d}-\mathrm{f}}$ & $15.9^{\mathrm{c}-\mathrm{h}}$ & 261 & $3.0^{\mathrm{cd}}$ & 100 & $34.5^{b-c}$ & $8.4^{\mathrm{bc}}$ & 211 \\
\hline Compost 2 & 2.5 & $29.7^{-a-c}$ & $16.3^{\mathrm{b}-\mathrm{c}}$ & 270 & $2.3^{\mathrm{h}}$ & 53 & $29.7^{\mathrm{b}-\mathrm{c}}$ & $6.3^{c-c}$ & 133 \\
\hline Compost 2 & 5.0 & $32.5^{\mathrm{ab}}$ & $17.4^{-a-c}$ & 295 & $3.1^{\mathrm{cd}}$ & 107 & $31.5^{\mathrm{b}-\mathrm{c}}$ & $11.3^{\mathrm{a}}$ & 319 \\
\hline Compost 3 & 2.5 & $27.7^{\mathrm{cf}}$ & $17.9^{\mathrm{ab}}$ & 307 & $3.4^{\mathrm{ab}}$ & 127 & $29.0^{c-c}$ & $4.4^{c-g}$ & 63 \\
\hline Compost 3 & 5.0 & $31.0^{a-c}$ & $18.0^{\mathrm{a}}$ & 309 & $3.5^{\mathrm{ab}}$ & 133 & $31.7^{\mathrm{b}-\mathrm{c}}$ & $8.8^{\mathrm{b}}$ & 226 \\
\hline Neem & 2.5 & $26.0^{c-g}$ & $15.2^{\mathrm{c}-\mathrm{j}}$ & 245 & $3.0^{\mathrm{cd}}$ & 100 & $28.0^{\mathrm{d}-\mathrm{f}}$ & $5.0^{\mathrm{cf}}$ & 85 \\
\hline Neem & 5.0 & $33.7^{\mathrm{a}}$ & $17.2^{a-c}$ & 291 & $3.3^{\mathrm{bc}}$ & 120 & $31.5^{\mathrm{b}-\mathrm{c}}$ & $9.7^{\mathrm{ab}}$ & 259 \\
\hline Poultry & 2.5 & $30.7^{a-c}$ & $17.0^{\mathrm{af}}$ & 286 & $3.3^{\mathrm{bc}}$ & 120 & $36.0^{a-c}$ & $7.6^{\mathrm{b}-\mathrm{d}}$ & 181 \\
\hline Poultry & 5.0 & $33.0^{\mathrm{ab}}$ & $17.3^{-\mathrm{ac}}$ & 293 & $3.4^{\mathrm{ab}}$ & 127 & $40.0^{\mathrm{a}}$ & $8.4^{\mathrm{bc}}$ & 211 \\
\hline A three ${ }^{\circ}$ & 1.0 & $26.5^{d-c}$ & $14.1^{f_{j}}$ & 220 & $2.9^{\mathrm{d}-\mathrm{f}}$ & 93 & $29.5^{\mathrm{b}-\mathrm{c}}$ & $6.3^{\mathrm{cec}}$ & 133 \\
\hline A three & 2.0 & $29.0^{\mathrm{b}-\mathrm{c}}$ & $15.1^{\mathrm{d}-\mathrm{i}}$ & 243 & $2.9^{\mathrm{d}-\mathrm{f}}$ & 93 & $37.0^{\mathrm{ab}}$ & $8.6^{\mathrm{b}}$ & 219 \\
\hline NPK & $1 / 2$ dose & $30.0^{a-c}$ & $16.6^{\mathrm{b}-\mathrm{f}}$ & 227 & $3.1^{\mathrm{cd}}$ & 107 & $31.5^{\mathrm{b}-\mathrm{c}}$ & $7.9^{b-d}$ & 193 \\
\hline NPK & rec. dose & $32.7^{\mathrm{ab}}$ & $18.2^{\mathrm{a}}$ & 314 & $3.6^{\mathrm{a}}$ & 140 & $33.0^{a-c}$ & $11.6^{\mathrm{a}}$ & 330 \\
\hline Control & & $20.7^{\mathrm{h}}$ & 4.41 & & $1.5^{\mathrm{ck}}$ & & $21.0^{\mathrm{f}}$ & $2.7^{\mathrm{g}}$ & \\
\hline
\end{tabular}

In each column, means followed by the same letter $(s)$ are not significantly different $(P \leq 0.05)$ according to Duncan's multiple range test 
creased significantly shoot and root fresh weights but not their lengths. In this regard, compost 2 , compost 3 , compound N P K and poultry accomplished the best results.

The present results showed that, compost 3 achieved very good results in both controlling the root-knot nematode and ameliorating the infected plants. These make it suitable for organic farming systems to keep nematode populations always under the economic threshold and improve plant performance if it used regularly.

Results of treatments included compost were significantly different from those of poultry or N P K and achieved overgrowth of the infected plants. The efficacy of compost seemed to depend upon the components of which it was produced. This may explain the differences observed in the present work between the three tested types of compost. The present results are in harmony with those of Moselhy (2009) who reported that compost significantly reduced the formation of galls on sunflower roots, the developmental stages and the final population by $84 \%$. Many other reports proved that compost application improved growth of infected plants and diminished nematode pop ulations (Cayuela, 2008; Lerog et al., 2007). The beneficial effects of compost on treated plants rather than its role in controlling nematodes are outlined by many others as it improves soil structure, porosity, increases infiltration and permeability of heavy soils, improves water holding capacity, supplies significant quantities of organic matter, improve cation exchange capacity, improves and stabilizes soil $\mathrm{pH}$, provides humus, vitamins, hormones and plant enzymes which are not supplied by chemical fertilizers (Ahmad et al., 2009; Evanylo et al., 2008; Field Guide to Compost Use, 2001; Rashad et al., 2010).

The dual effect of N P K in improving plant growth and suppressing nematode populations is documented (Akhtar and Mahmood, 1996).

\section{Biochemical alterations in tomato plants as influenced by Meloidogyne incognita and application of organic and inorganic fertilizers \\ Biochemical alterations in tomato roots and shoots as a} result of the root-knot nematode infection and application of organic and inorganic fertilizers are illustrated in Fig. 1

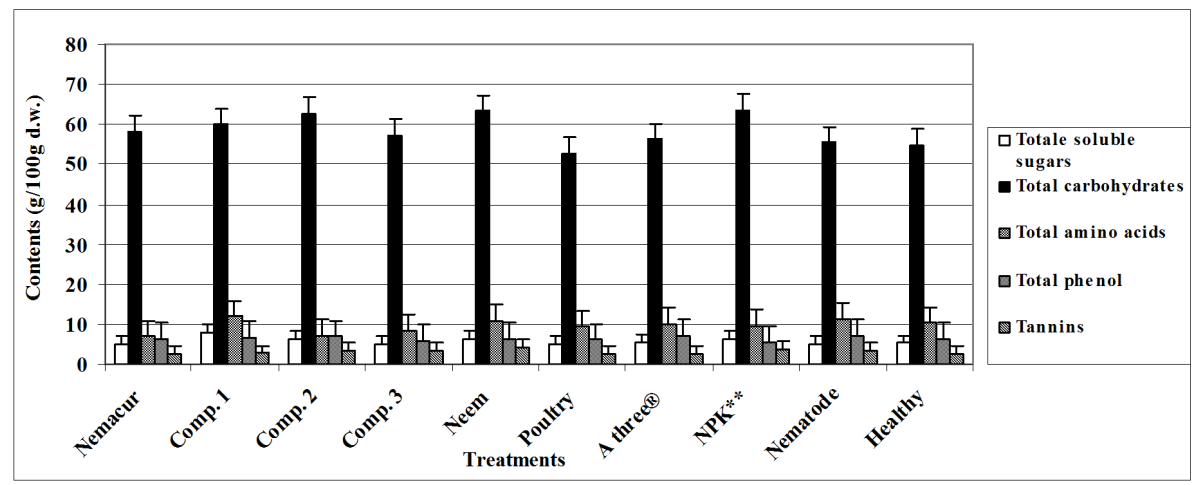

Fig. 1. Biochemical contents (g/100 g d.w.) alterations in tomato roots as influenced by $M$. incognita infection and the application of organic and inorganic fertilizers.

Treatments dose (g/pot): Nemacur (10\% G): 0.2; Comp. (Compost) 1, 2, 3: 5 g/pot; Neem (dry leaves): 5 g/pot; Poultry (droppings): $5 \mathrm{~g} /$ pot; A three (three types of compost): $2 \mathrm{~g} /$ pot; $\mathrm{N} \mathrm{P} \mathrm{K}^{* *}$ (recommended dose); Nematode: Nematode only; Healthy: Untreated healthy

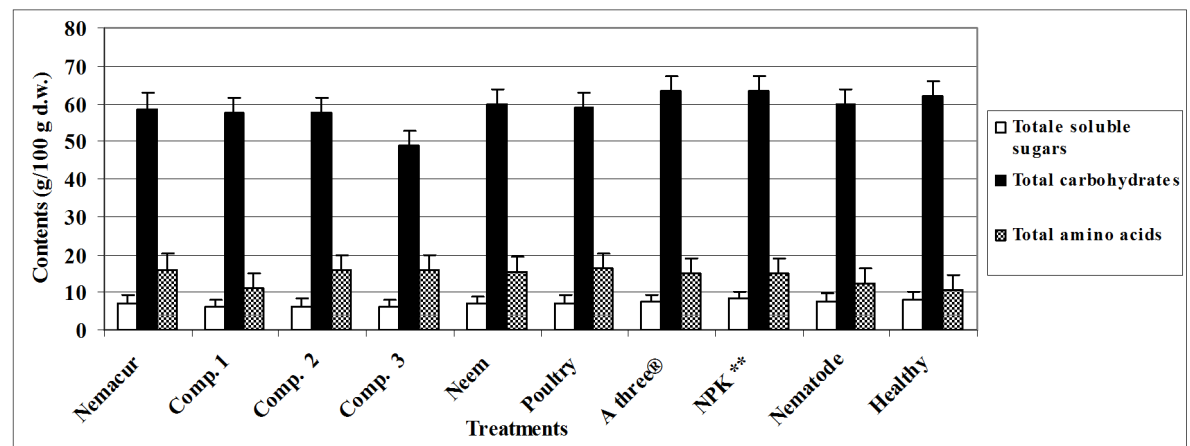

Fig. 2. Alterations in tomato shoots contents (g/100 g d.w.) of soluble sugars, carbohydrates and amino acids as directed by $M$. incognita infection and the application of organic and inorganic fertilizers.

Treatments dose (g/pot): Nemacur (10\%G): 0.2; Comp. (Compost) 1, 2, 3: 5 g/pot; Neem (dry leaves): 5 g/pot; Poultry (droppings): $5 \mathrm{~g} /$ pot; A three ${ }^{\circ}$ (three types of compost): $2 \mathrm{~g} /$ pot; $\mathrm{N} \mathrm{P} \mathrm{K}^{* *}$ (recommended dose); Nematode: Nematode only; Healthy: Untreated healthy 
52

and 2 . In roots, nematode infection reduced the total soluble sugars by $6.7 \%$. However, all treatments (except poultry droppings) increased roots content of soluble sugars as compared to infected untreated tomato plants. Moreover, compost 1, 2, neem, A three and N P K increased total soluble sugars over the untreated healthy plants. Almost similar results were observed with total carbohydrates.

In contrast, nematode infection boosted roots contents of amino acids, total phenols and tannins. Almost all treatments (except compost 1, and neem) diminished roots content of total amino acids. Nemacur $10 \% \mathrm{G}$ achieved the greatest diminution, $31.79,38.24 \%$ from those recorded in untreated healthy and untreated infected plants, respectively.

Also, all treatments brought phenol contents back to be almost near to those in the untreated healthy plants except for compost 2 and the A three which were very close to those recorded in infected untreated plants. Tannins rose in tomato roots after nematode infection; the majority of treatments accomplished the same results.

Neem treatment raised content of tannins by approximately 1.5 times over those in the healthy plants, however, nemacur, poultry droppings and A three failed to increase tannins over the untreated healthy roots.

In shoots (Fig. 2), nematode infection decreased the total soluble sugars and total carbohydrates. All treatments failed to reimburse soluble sugars and carbohydrates except for the prepared N P K and A three ${ }^{\varpi}$, in that order. Nematode infection increased shoots total amino acids content by $18.63 \%$. All treatment (except compost 1 ) also increased total amino acids in shoots but with higher percentages with preponderancy of poultry droppings followed by nemacur and all compost treatments.

With plants content of N P K, the root-knot nematode infection precluded tomato uptake of the three elements Fig. 3. Treating infected plants with the organic and inorganic fertilizers perked up plants uptake but only few treatments enabled plants to stand with the uninfected healthy ones, A three ${ }^{\oplus}$, prepared N P K and compost 1 were the best with N P and K, respectively. Generally the prepared N P K gave the over all best results, however nemacur improved plants uptake of nitrogen only.

It was generally postulated that the adverse influence of organic amendments on phytoparasitic nematodes is referred to numerous factors e.g. increasing host resistance to nematode infection and enhancement of growth performance (Courtney and Mullen, 2008), changing physical soil properties like cation exchanges, water retention and soil arrogation (Alam et al., 1977), producing chemicals during degradation like volatile fatty acids, organic acids, phenols, hydrogen sulphide and nitrogenous compounds (Al-Sayed et al., 2007; Kesba and Al-Shalaby, 2008; McBride et al., 2000; Zaki et al., 2004).

Treating infected plants with fertilizers improve the performance of infected plants by enabling them to recompense root losses of soluble sugars and total carbohydrate and brought phenol contents back to be almost near to those in untreated healthy plants, raising tannins content, diminishing root contents of amino acids to be around those in healthy plants. In the above ground parts of the infected plants, almost all treatments improved plants uptake of nitrogen, however, only prepared N P K improved P and compost 1 improved K. Similarly, mineral fertilizers increased shoots content of total sugars and total carbohydrates.

The reduction in soluble, reducing and non reducing sugars, total carbohydrates in different host plants due to nematodes infection was recorded by many research workers (Farahat et al., 2007; Kheir and Abadir, 1982; Parveen et al., 2006; Sharma and Trivedi, 1997; Shuying and Zhixin, 1999). However, an opposed results were recorded by (Alam et al., 1976; Jain and Kant, 1991). Others did not find any pronounced effects of $M$. javanica or $M$. incognita on sugar content (Singh and Chaudhury, 1974).

Concerning N P K levels in plants infected with the root-knot nematodes, Nasr et al. (1980) showed that $M$. incognita and $M$. javanica infection increased phosphorous and nitrogen concentrations in bitter almond. Also, M. incognita increased nitrogen content of okra (Sharma and Trivedi, 1997). High levels of nitrogen, phospho-

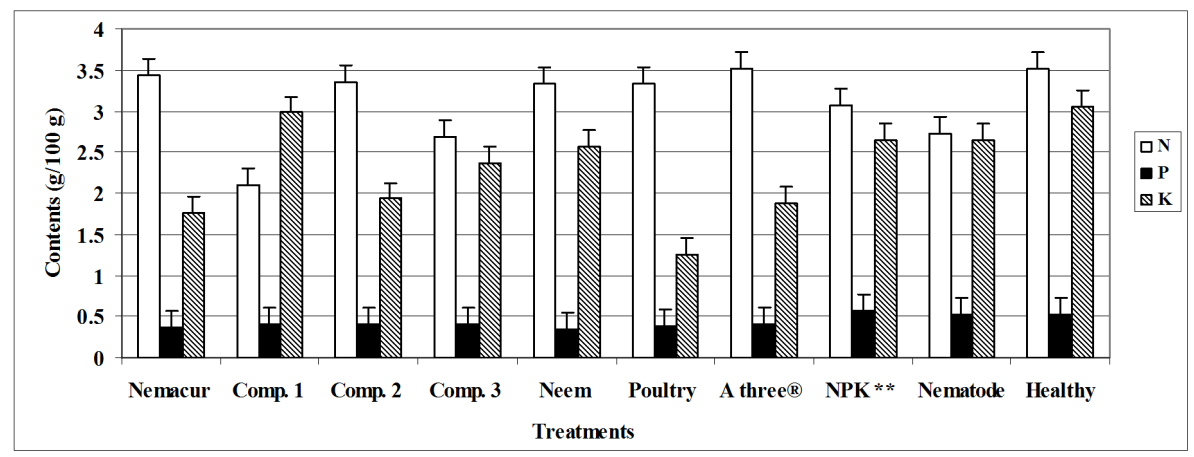

Fig. 3. Tomato shoots contents of N P K affected by M. incognita infection and the application of organic and inorganic fertilizers.

Treatments dose (g/pot): Nemacur (10\%G): 0.2; Comp. (Compost) 1, 2, 3: 5 g/pot; Neem (dry leaves): 5 g/pot; Poultry (droppings): $5 \mathrm{~g} /$ pot; A three ${ }^{\circ}$ (three types of compost): $2 \mathrm{~g} /$ pot; $N \mathrm{P} \mathrm{K}^{* *}$ (recommended dose); Nematode: Nematode only; Healthy: Untreated healthy 
rous and potassium occurred in root-knot infected than healthy tomato roots (Hunter, 1958; Shafiee and Jenkins, 1963). But the lower contents of minerals in heavily galled tomato roots was illustrated by Oteifa and El-Gindi (1962), when they showed that heavily galled roots can't translocate adequate amounts of nutrients to vegetative organs whereas tomato foliage infected with $M$. incognita have been shown to contain lower concentrations of N P $\mathrm{K}$, sodium, calcium and magnesium.

The phenolic compounds are the best known factors involved in susceptible-resistant response. There is a distinct correlation between the degree of plant resistance and the phenolics present in plant tissues (Abdel-Rahim and El-Beltagi, 2010, 2011; El-Beltagi and Mohamed, 2010; Giebel, 1970; Mohamed et al., 2010). Most phenols occur in plant tissues in bound forms as glycosides of low physiological and chemical activities. Activation requires their decompositions to free phenols (Afify et al., 2011, 2012; El-Beltagi, 2011, El-Beltagi et al., 2011a, 2011b, 2011c; Giebel and Wilski, 1970; Kesba and ElBeltagi, 2012; Shallan et al., 2010; Shehab et al., 2010). Nematodes are able to decompose glycosides by secreting $\beta$-glycosidases into host tissue (Masseneer, 1964; Wilski and Giebel, 1966).

Tannins are among the chemicals that reduced by nematode infection, it had been shown that tannins are utilized in the formation of necrotic areas around nematodes in resistant host plants, accordingly, tannins increased in such kind of hosts after effect of nematodes (Farahat $e t$ al., 2007; McAvoy et al., 1998). However, this is not the case in susceptible hosts like those under the present study.

\section{Acknowledgments}

Authors would like to thank the management of the Faculty of Agriculture, Cairo University for ongoing cooperation to support research and that provided funds and facilities necessary to achieve the desired goals of research.

\section{References}

Abdel-Rahim EA, El-Beltagi HS (2011). Alleviation of hyperlipidemia in hypercholesterolemic rats by lentil seeds and apple as well as parsley in semi-modified diets. Adv Food Sci 33(1):2-7.

Abdel-Rahim EA, El-Beltagi HS (2010). Constituents of apple, parsley and lentil edible plants and their therapy treatments for blood picture as well as liver and kidneys functions against lipidemic disease. EJEAFChe 9(6):1117-1127.

Afify AMR, El-Beltagi HS, Abd El-Salam SM, Omran AA (2012). Biochemical changes in phenols, flavonoids, tannins, vitamin $\mathrm{E}, \beta$-carotene and antioxidant activity during soaking of three white sorghum varieties. APJTB 2(3):203-209.

Afify AMR, El-Beltagi HS, Fayed SA, Shalaby EA (2011). Acaricidal activity of different extracts from Syzygium cumini L. Skeels (Pomposia) against Tetranychus urticae Koch. APJTB 1(5):359-364.

Ahmad N, Hassan F, Belford R (2009). Effects of soil compaction in the sub-humid cropping environment in Pakistan on uptake of N P K and grain yield in wheat (Triticum aesitivum) II, Alleviation. Field Crops Res 110:61-68.

Ahmad F, Siddiqui MD (2009). Management of root-knot nematode Meloidogyne incognita in tomato. Pak J Nematol 27(2):369-373.

Akhtar M, Mahmood I (1996). Control of plant-parasitic nematodes with organic and inorganic amendments in agricultural soil. App Soil Ecol 4(3):243-247.

Akhtar M, Siddiqui ZA, Mahmood I (1998). Management of Meloidogyne incognita in tomato by some inorganic fertilizers. Nematologia Mediterranea 26(1):23-25.

Akhtar M, Malik A (2000). Roles of organic soil amendments and soil organisms in the biological control of plant parasitic nematodes. A review. Bioresource Technol 74:35-47.

Alam MM, Ali QG, Masood A, Khan AM (1976). Studies on the chemical changes induced by the infection of the root-knot nematode (Meloidogyne incognita) in tomato and eggplant and the stunt nematode (Tylenchorhynchus brassicae) in cabbage and cauliflower roots. Ind J Exp Biol $14(4): 517-518$.

Alam MM, Siddiqui SA, Khan AM (1977). Mechanism of control of plant parasitic nematodes as a result of application of organic amendments to the soil. III Role of phenols and amino acids in host roots. Ind J Nematol 7:27-31.

Al-Rehiayani SM (2001). Organic and inorganic fertilizers in relation to the control of the root-knot nematode, Meloidogyne javanica infecting tomato. Egypt J Agronematol 5(1-2):1-9.

Al-Sayed AA, Kheir AM, El-Naggar HI, Kesba HH (2007). Organic management of Meloidogyne incognita on grapes in relation to host biochemistry. Internat J Agric Res 2(9):776785.

Anjum A, Alam MM, Ahmed A (1996). Efficacy of some organic amendments against reniform nematode, Rotylenchulus reniformis on black gram. Ann Plant Protec Sci 4(2):122 125.

A.O.A.C. (1995). Methods of Analysis, Association of Official Agriculture Chemists. $14^{\text {th }}$ ed., Washington, D.C., USA, $1094 \mathrm{p}$.

Burns ER (1971). Method for estimation of tannin in grain sorghum. Argon J 63:511-519.

Cayuela MI, Millner PD, Myer SL, Roig A (2008). Potential of olive mill waste and compost as biobased pesticides against weeds, fungi and nematodes. Sci Total Environ 309:11-18.

Chow PS, Landhausser SM (2004). A method for routine measurements of total sugars and starch content in woody plant tissues. Tree Physiol 24:1129-1136.

Courtney RG, Mullen GJ (2008). Soil quality and barley growth as influenced by land application of two compost types. 
54

Bioresource Technol 99:2913-2918.

Crow WT, Dunn RA (1994). Soil organic matter, green manures and cover crops for nematode management. University of Florida, IFAS Extension. http//edis.ifas.ufl.edu.

Efthimiadou A, Bilalis D, Karkanis A, Froud-Williams B, Eleftherochorinos I (2009). Effects of cultural system (organic and conventional) on growth, photosynthesis and yield components of sweet corn (Zea mays L.), under semiarid environment. Not Bot Horti Agrobo 37(2):105-111.

Efthimiadou A, Bilalis D, Karkanis A, Froud-Williams B (2010). Combined organic/inorganic fertilization enhance soil quality and increased yield, photosynthesis and sustainability of sweet maize crop. Aust J Crop Sci 4(9):722-729.

El-Beltagi HS (2011) Effect of roasting treatments on protein fraction profiles, some enzyme activities of Egyptian peanuts. Int J Food Sci Nutr 62(5):453-456.

El-Beltagi HES, Mohamed AA (2010). Variation in fatty acid composition, glucosinolate profile and some phytochemical contents in selected oil seed rape (Brassica napus L.) cultivars. Grasas Y Aceites 61(2):143-150.

El-Beltagi HS, Mohamed AA, Mekki BB (2011a). Differences in some constituents, enzymes activity and electrophoretic characterization of different rapeseed (Brassica napus L.) cultivars. Analele Universității din Oradea-Fascicula Biologie Tom XVIII (1):39-46.

El-Beltagi HS, Kesba HH, Abdel-Alim AI, Al-Sayed AA (2011b). Effect of root-knot nematode and two species of crown gall on antioxidant activity of grape leaves. Afr J Biotechnol 10(57):12202-12210

El-Beltagi HS, Salama ZA, El-Hariri DM (2011c). Variations in oil and some phytochemical contents in flaxseed cultivars (Linum usitatissimum L.). EJEAFChe 10(8):2711-2721.

El-Merzabani MM, El-Aaser AA, Zakhary NI (1997). Determination of inorganic phosphorus in serum. J Clin Chem Clin Biochem 15:715-718.

Etsushiro D, Daisuke S, Eruyoshi M (1981). Modified colorimetric ninhydrine method for peptidease assay. Anal Biochem 118:173-184.

Evanylo G, Sherony C, Spargo J, Starner D, Brosius M, Haering K (2008). Soil and water environmental effects of fertilizer, manure and compost-based fertility practices in an organic vegetable cropping system. Agric Ecosys Environ 127:5058 .

Farag RS, Hallabo SAS, Hewedi FM, Basyony AE (1986). Chemical Evaluation of Rape seed. Fette-Seifen Anstrichmittel 88 (10):391-397.

Farahat AA, Al-Mihanna AA, Belal MM (1999). Effect of adding chicken manure and eucalyptus dry leaves powder on root galling and growth of sunflower. J Agric Sci, Mansoura Univ 24(8):4226-4229.

Farahat AA, El-Naggar HI, Hendy HH, El-Gonaimy AM (2008). Management of the root-knot nematode, $M$. incognita infecting peach, Pruns persica under greenhouse conditions. Egypt J Agronematol 6(2):127-146.

Farahat AA, Hendy $\mathrm{HH}$, El-Naggar HI, El-Ghonaimy AM (2007). Biochemical changes in resistant and susceptible peach root-stocks after effect of the root-knot nematode, Meloidogyne incognita. J Agric Sci, Mansoura Univ 32(5):3733-3744.

Field Guide to Compost Use (2001). Field Guide to Compost Use. U.S. Composting Council, 1 Comac Loop, Suite 14 Bl Ronkonkoma, New York, 1779 p.

Giebel J (1970). Phenolic content in roots of some Solanaceae and its influence on IAA-oxidase activity as an indicator of resistance to Heterodera rostochiensis. Nematologica 16:2232.

Giebel J, Wilski A (1970). The role of IAA oxidase in potato resistance to Heterodera rostochiensis. Proc. Ninth Int. Nematol. Symp., Eur. Soc. Nematol. Warsaw 1467. Zeszyty problem. Post Nauk Rol 92:239-245.

Holme JD, Peck H (1983). Analytical Chemistry, Longman, New York. Inc., 436-467 p.

Hunter AH (1958). Nutrient absorption and translocation of phosphorous as influenced by the root-knot nematode Meloidogyne incognita. Soil Sci 86:245-250.

Jain P, Kant U (1991). Changes in carbohydrate contents and hydrolying enzymes in root-knot of vigna radiation infected by Meloidogyne incognita in vivo and in vitro. J Phytol Res 4(2):187-188.

Kesba HH, El-Beltagi HS (2012). Biochemical changes in grape rootstocks resulted from humic acid treatments in relation to nematode infection. APJTB 2(4)287-293.

Kesba HH, Al-Shalaby Mona E (2008). Survival and reproduction of Meloidogyne incognita on tomato as affected by humic acid. Nematol 10(2):243-249.

Kheir AM, Abadir SK (1982). Effect of Meloidogyne incognita on carbohydrate contents of potato plants. Res Bull, Fac Agric, Zagazig Univ 480:1-12.

Kheir AM, Al-Sayed AA, Saeed MR (2009). Suppressive effects of inorganic fertilizers on $M$. incognita infecting soybean. Egypt J Agronematol 7(1):9-19.

Lerog M, Bommele L, Reheul D, Moens M, De Neve S (2007). The application of vegetable, fruit and garden waste (VFG) compost in addition to cattleslurry. L Plant Sci 170(2):274282.

Masseneer JDE (1964). Leaf browing of Ficus Sp. New host plants of Aphelenchoids fragariae (Ritzema Bos). Nematologica 10:403-408.

McAvoy RJ, Binle BB, Evans MR(1998). Localized accumulation of condensed tannins associated with poinsettia bract necrosis. J Am Soc for Hort Sci 123(5):916-920

McBride RG, Mikkelsen RL, Barker KR (2000). The role of low molecular weight organic acids from decomposing rye in inhibitng root-knot nematode populations in soil. Appl Soil Ecol 15:243-251.

McSorley R, Ozores-Hampton M, Stansly PA, Conner JM 
(1999). Nematode management, soil fertility and yield in organic vegetable production. Nematropica 29(2):205-213.

Meda A, Lamien CE, Romito M, Millogo J, Nacoulma OG (2005). Determination of total phenolic, flavonoid and proline contents in Burkina Fasan honey as well as their radical scavenging activity. Food Chem 91:571-577.

Mohamed AA, Khalil AA, El-Beltagi HES (2010). Antioxidant and antimicrobial properties of kaff maryam (Anastatica hierochuntica) and doum palm (Hyphaene thebaica). Grasas Y Aceites 61(1):67-75.

Moselhy MA (2009). Bioconversion of Rice Straw and Certain Agro-Industerial Wastes to Fertilizers for Organic Farming Systems. Ph.D. Thesis. Fac, Agric, Cairo Univ, Egypt, 221 p.

MSTAT-C (1989). Statistical package software program for the design and analysis of research experiment, Michigan State University, USA.

Nasr TA, Ibrahim IKA, El-Azab EM, Hassan MWA (1980). Effect of root-knot nematode on the mineral, amino acid and carbohydrate concentration of almond and peach rootstocks. Nematologica 26(2):133-138.

Oteifa BA (1955). Nitrogen source of the host nutrition in relation to infection by a root-knot nematode Meloidogyne incognita. Plant Dis Reporter 39:902-903.

Oteifa BA, El-Gindi DM (1962). Influence of parasitic duration of Meloidogyne javanica (Treub) on host nutrient uptake. Nematologica 8:216-220.

Parveen K, Haseeb A, Shukla PK (2006). Pathogenic potential of Meloidogyne incognita on Mentha arvensis cv. Gomti. Ind J Nematol 36(2):177-180.

Rashad FM, Saleh WD, Moselhy MM (2010). Bioconversion of rice straw and certain agro-industrial wastes to amendments for organic farming systems. I-composting, quality, stability and maturity indcies. Bioresource Technol 101:5951-5960.

Shafiee MF, Jenkins WR (1963). Host-parasitic of Capsicum frutessens and Pratylenchus penetrans, Meloidogyne incognita acrita and Meloidogyne hapla. Phytopathol 53:325-328.
Shallan MA, El-Beltagi HS, Mona A, Amera TM (2010) Chemical Evaluation of Pre-germinated Brown Rice and Whole Grain Rice Bread. EJEAFChe 9(3):958-971.

Sharma W, Trivedi PC (1997). Biochemical evaluation of various metabolites as influenced by root-knot nematode in Abelmoschus esculentus. Ind J Nematol 26(2):152-157.

Shehab GG, Kansowa OA, El-Beltagi HS (2010) Effects of various chemical agents for alleviation of drought stress in Rice plants (Oryza sativa L.). Not Bot Horti Agrobo 38(1):139-148.

Shuying B, Zhixin F (1999). Changes in the growth hormones, free amino acids, nucleic acids and sugar contents of peanut plants infected by Meloidogyne arenaria. J South China Agric Univ 20(4):15-19.

Singh B, Chaudhury B (1974). Screening tomato cultivars for resistance to Meloidogyne species. Pest Articles and News Summaries 20(3):319-322.

Sinha AK, Neog PP (2003). Effect of different levels of N P K fertilizers against citrus nematode (Tylenchulus semipenetrans) on Khasi mandarin. Ind J Nematol 33(1):6162.

Strilling GR (1991). Biological Control of Plant Parasitic Nematodes. CAB International, Wallingford, UK.

Wilski A, Giebel J (1966). $\beta$ glucosidase in Heterodera rostochiensis and its significance in resistance of potato of this nematode. Nematologica 12:214-224.

Zaki FA, Bahati DS (1989). Phytotherapeutic effect of some plant leaves on Meloidogyne javanica infecting tomato plants. Nematologia Mediterranea 17(2):71-72

Zaki MJ, Javad S, Abid M, Khan H, Moinuddin M (2004). Evaluation of some chemicals against root-knot nematode, Meloidogyne incognita. Intr J Biol Biotecnol 1:613-618.

Zhang S, Zhang X (2009). Effects of two composted plant pesticide residues incorporated with Trichoderma viride on root-knot nematode in ballon flower. Agric Sci China $8(4): 447-454$. 